\title{
Assessment of LULC Changes for Hesaraghatta Watershed Using GIS Tools and Remote Sensed Data
}

\author{
Bharath A.*†, Manjunatha M.*, Ranjitha B. Tangadagi*, Preethi S.** and Mukund Dangeti*** \\ *Department of Civil Engineering, GITAM School of Technology, GITAM University, Bangalore-562163, Karnataka, \\ India \\ **School of Civil Engineering, REVA University, Bangalore-560024, Karnataka, India \\ ****Department of Civil Engineering, GITAM Institute of Technology, GITAM University, Visakhapatnam-530045, \\ Andhra Pradesh, India \\ $\dagger$ Corresponding author: Bharath A.; bashu@ gitam.edu
}

\author{
Nat. Env. \& Poll. Tech. \\ Website: www.neptjournal.com \\ Received: 11-01-2021 \\ Revised: 15-02-2021 \\ Accepted: 24-02-2021 \\ Key Words: \\ Change detection \\ Landsat \\ Remote sensing and GIS \\ Land use/land cover \\ Image classification
}

\begin{abstract}
Hesaraghatta watershed is one of the most vital and environmentally substantial watersheds in the Arkavathi basin. It has a freshwater lake created in the year 1894 across the Arkavathi River to quench the drinking water requirements of Bengaluru city. The watershed is facing significant stresses due to rapid urbanization and other developmental activities. For this study, an attempt is made to assess the distribution of various land use land cover classes and their temporal changes over 18 years using remote sensed data and GIS tools. The watershed is categorized into four land use land cover classifications: settlement, waterbody, vegetation, and bare soil. The maximum likelihood technique is utilized for the image classification and accuracy assessment is carried out to evaluate the accuracy of image classification. The outcome of the study revealed that there is a substantial change in land use land cover classes in the Hesaraghatta watershed.
\end{abstract}

\section{INTRODUCTION}

From the start of human civilization, humankind has been in a close association with nature and its reliance on the environment is greater than any other living thing (Anees et al. 2017, Wang et al. 2018). Due to the intensification in population and human intervention, there is a substantial modification in Land use (LU) and Land cover (LC) with time. In general, "land cover refers to the physical land kind such as how much of a region is enclosed by forests, impervious surfaces, agricultural lands, wetlands, and open water, whereas land use documents how people are using the land for development, conservation or mixed uses (Chowdhury et al. 2020). LULC changes greatly affect the regional ecological process (Chowdhury et al., 2020), (Belay \& Mengistu 2019). Water quality, runoff and groundwater recharge, etc., gets affected due to changes in LULC in a watershed (Butt et al. 2015, Garg et al. 2019). Thus, it becomes necessary to understand the spatial relationship and mechanisms between ecosystem and LULC (Chen et al. 2019, Imran Basha et al. 2018, Salunke \& Chavan 2020) and to measure the changes in LULC pattern at the watershed level for planning management strategies (Nayak \& Byrne 2019, Preethi et al. 2020, L. Wang et al. 2020). Assessment of LULC change helps to identify the amount of anthropological impact on the natural environment (Chowdhury et al. 2020). Change detection is a method to identify the condition of a component or phenomenon by perceiving it at a different time (Bharath et al. 2020a, Imran Basha et al. 2018). Change detection helps to identify LULC changes like landscape changes, shifting cultivation, land degradation, desertification, urban sprawl, coastal change, deforestation, quarrying activities, and other cumulative changes (Bharath et al. 2020b, Gebeyehu et al. 2019).

Traditional approaches are not satisfactory for the analysis of multi-complex environmental investigations because of the difficulty of dealing with the multi-disciplinary dataset; hence we need new advances like remote sensing and Geographical Information Systems (GIS) (Mallupattu \& Sreenivasula Reddy 2013). GIS and Remote sensing are the most efficient approaches for observing widespread and rapid LULC changes (Ali et al. 2020, Tsai et al. 2019). Remotely sensed data is freely accessible, and developments in spatial, spectral, and temporal resolutions continue to provide tools for detecting changes in LULC at various scales. Landsat satellite systems provide open-access, long-term imageries that are ideal for assessing LULC change (Tsai et al. 2019). 
The primary objective of this LULC study is to determine the extent of LULC changes that arisen in the Hesaraghatta Watershed from 2000 to 2018. But the definite objectives are delineating the Hesaraghatta watershed, detecting the changes in LULC classes within the watershed by spatial comparison, and analyzing the capability of integrating GIS with Remote sensing to study the spatial distribution of LULC classes.

\section{Study Area}

Hesaraghatta watershed is situated in Bengaluru rural district, and geographically it lies in $77^{\circ} 20^{\prime}$ and $77^{\circ} 42^{\prime}$ E longitude and $13^{\circ} 10^{\prime}$ and $13^{\circ} 24^{\prime} \mathrm{N}$ latitude as shown in Fig. 1. Hesaraghatta watershed is one of the most vital and environmentally substantial watersheds. It has a freshwater lake created in the year 1894 across the Arkavathi River Arkavathi River to quench the drinking water requirements of Bengaluru city. The watershed spreads over an area of about $605.2 \mathrm{~km}^{2}$ with a width and length of $27.28 \mathrm{~km}$ and $33.36 \mathrm{~km}$, respectively (Somashekar et al. 2011).

\section{MATERIALS AND METHODS}

Fig. 2 Shows the process flow chart for change detection \& LULC mapping.

\section{Data Acquisition}

In this study, Cartosat-1: DEM - Version-3R1 collected from the Bhuvan website (https://bhuvan.nrsc.gov.in/) is used for watershed delineation. Satellite images of two different years comprising of multi-spectral data procured via Landsat provided by the United States Geological Survey (USGS) Earth Explorer (EarthExplorer n.d.) are used for visual image interpretation and detecting LULC classes. Images collected are of the same months to have minimal seasonal variation (Chowdhury et al. 2020). Table 1 highlights the different data that are used in this study.

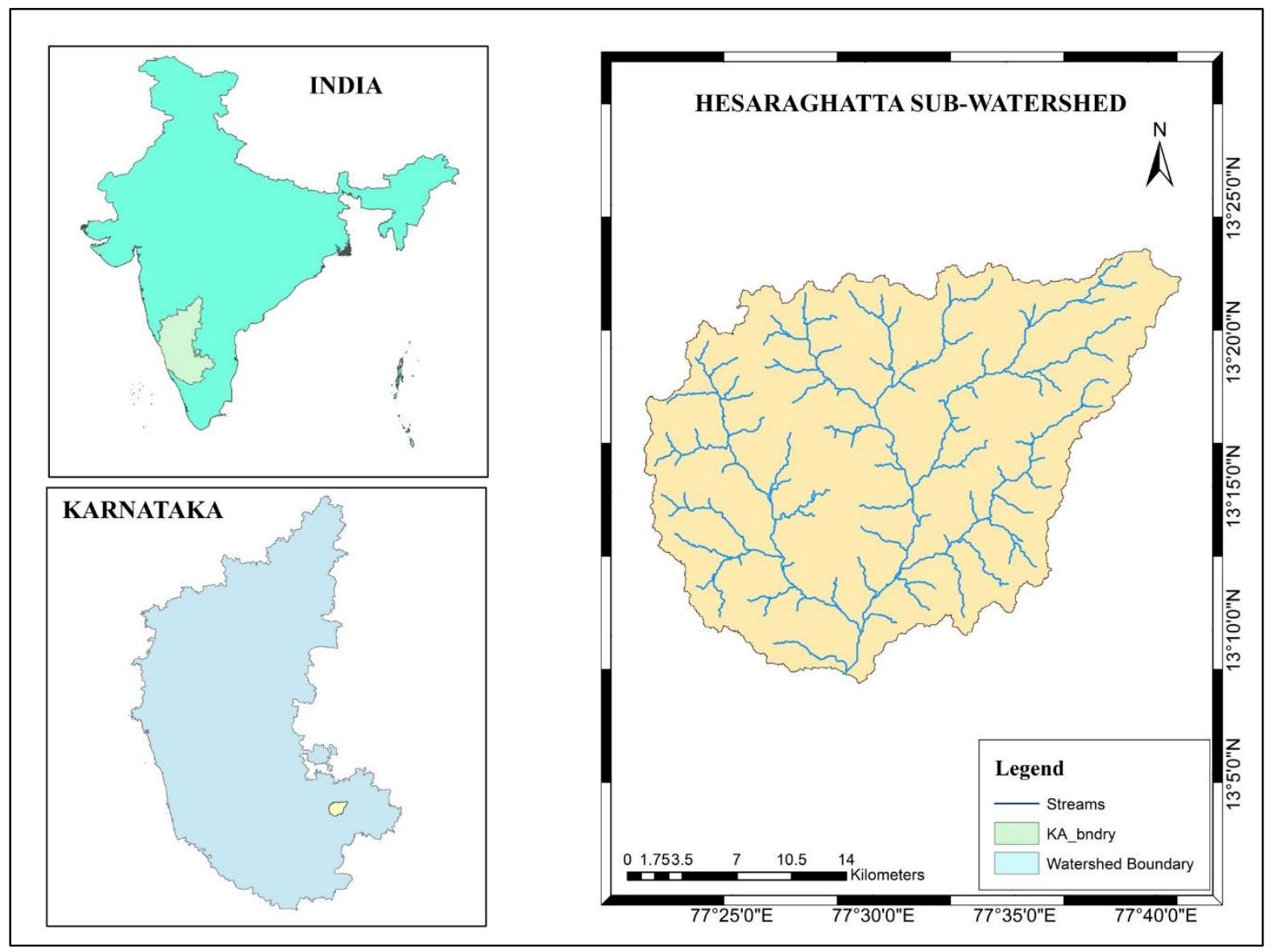

Fig. 1: Location of Hesaraghatta Watershed. 


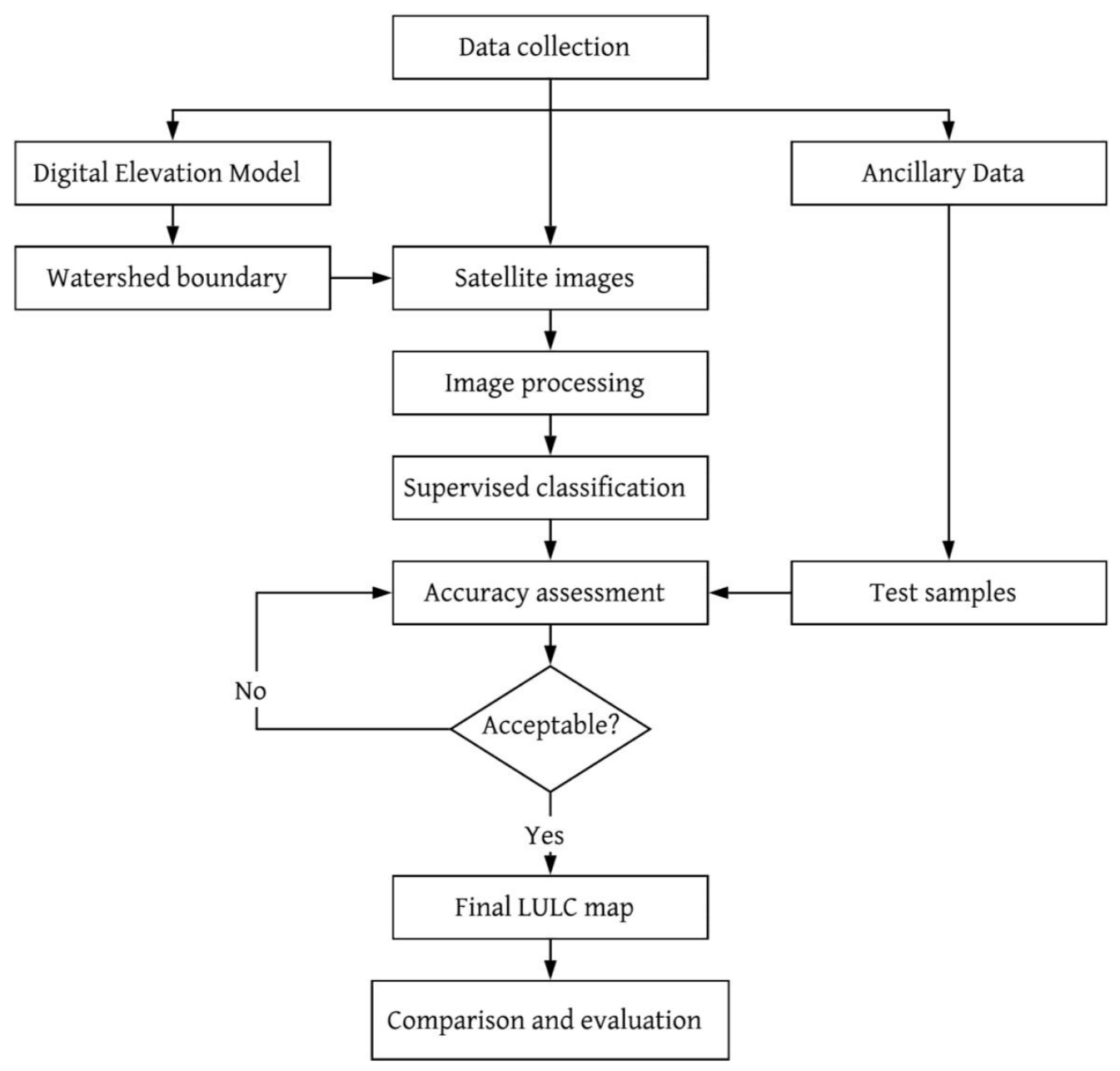

Fig. 2: Methodology for LULC mapping and change detection.

Table 1: Details about the study area.

\begin{tabular}{|lllll|}
\hline Data & Source & Satellite & Date of acquisition & Properties \\
\hline DEM & Bhuvan website & Cartosat-1: DEM & 2014 & $32 \mathrm{~m}$ resolution \\
& bhuvan.nrsc.gov.in & Version-3R1 & & $30 \mathrm{~m}$ resolution \\
Satellite images & USGS-Earth Explorer & 2000 - Landsat 7 & $16 / 03 / 2000$ & $11 / 04 / 2018$ \\
& (earthexplorer.usgs.gov) & 2018 - Landsat 8 & \\
\hline
\end{tabular}

\section{Watershed Delineation}

Watershed delineation is a process of marking a boundary that signifies the area contributing to an outlet (Chowdhury et al. 2020, Rimal et al. 2019). In this research, Cartosat-1 DEM of the study area with a spatial resolution of $30 \mathrm{~m}$ and QGIS software is used for delineating the watershed. Fig. 3 highlights the process flow diagram for delineating the boundary of the watershed.

\section{Image Pre-Processing \& Image Classification}

Before image classification, satellite images are enhanced using histogram equalization to increase accuracy (Mallupattu $\&$ Sreenivasula Reddy 2013). The resultant satellite images are clipped using the Hesaraghatta watershed boundary. A supervised image classification technique is used for image classification. In supervised classification, training sites are defined by the user based on the pixel signature (Chowdhury 


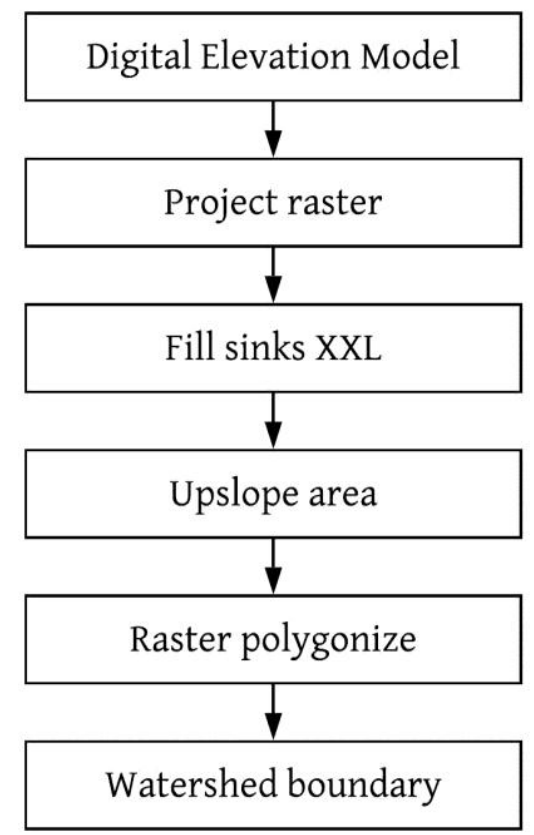

Fig. 3: Process flow diagram for watershed delineation.

et al. 2020, Mallupattu \& Sreenivasula Reddy 2013) Both image processing and image classification are done using ERDAS imagine V15. The entire watershed is distinguished into four LULC classes, i.e., vegetation, settlement, bare soil, and water body. For every LULC class, polygons were drawn to training sites. Hence, signatures are located in satellite images by using Google Earth Pro images (Das Kangabam et al. 2019, Tsai et al. 2019) Maximum likelihood algorithm is used for supervised image classification.

\section{Accuracy Assessment}

It is a process that compares the classified pixels with the ground-truth points to assess how well the classified image signifies the real world (Chowdhury et al. 2020, Das Kangabam et al. 2019). In the present study, overall accuracy and kappa coefficient are determined to check the accuracy of image classification. This is done by a random sampling method using 200 points based on ground truth data (Abd El-Kawy et al. 2011, Das Kangabam et al. 2019, Tsai et al. 2019)

\section{LULC Change Assessment}

After image classification, LULC maps of the years 2000 and 2018 are obtained, which gives information about LULC distribution in the study area. Further, the classified images of two time periods are compared to estimate LULC changes over time (Chowdhury et al. 2020).

\section{RESULTS AND DISCUSSION}

Hesaraghatta watershed is delineated using Cartosat-1 DEM of $30 \mathrm{~m}$ resolution by the QGIS tool. The watershed spreads over an area of $605.2 \mathrm{~km}^{2}$. By applying the supervised image classification technique, Landsat data for the years 2000 and 2018 are classified under four LULC classes. The outcomes show that in the year 2000, an area of $98.3 \mathrm{~km}^{2}$ was covered with vegetation, $1.1 \mathrm{~km}^{2}$ with water, $431.1 \mathrm{~km}^{2}$ with bare soil, and $74.6 \mathrm{~km}^{2}$ with settlement, whereas in the year 2018 , $125.6 \mathrm{~km}^{2}$ of the area was covered with vegetation, $2.5 \mathrm{~km}^{2}$ with water, $153.3 \mathrm{~km}^{2}$ with settlement, and $125.6 \mathrm{~km}^{2}$ with bare soil (Table 2). Fig. 4 and Fig. 5 show the LULC maps of the year 2000 and 2018 respectively and Fig. 6 highlights the circulation of different LULC classes in the Hesaraghatta watershed for the years 2000 and 2018. In the results, bare soil includes both barren lands as well as agricultural fallow land because the study area falls under the semi-arid zone. Most of the agricultural activities depend on rainfall only whereas the satellite data which is considered is of the summer season..

Upon comparing the LULC maps of the years 2000 and 2018, it is found that there was a massive change in the distribution of LULC classes. Between the years 2000 and 2018, the settlement increased from $74.6 \mathrm{~km}^{2}$ to 153.3 $\mathrm{km}^{2}$, vegetation increased from $98.3 \mathrm{~km}^{2}$ to $125.6 \mathrm{~km}^{2}$, 
Table 2: LULC distribution in Hesaraghatta watershed from 2000 to 2018.

\begin{tabular}{|lllll|}
\hline \multirow{2}{*}{ LULC class } & LULC in 2000 & & LULC in 2018 \\
\cline { 2 - 5 } & $\begin{array}{l}\text { Area } \\
\left(\mathrm{km}^{2}\right)\end{array}$ & $\begin{array}{l}\text { Percentage } \\
(\%)\end{array}$ & $\begin{array}{l}\text { Area } \\
\left(\mathrm{km}^{2}\right)\end{array}$ & $\begin{array}{l}\text { Percentage } \\
(\%)\end{array}$ \\
\hline Water & 1.1 & 0.18 & 2.5 & 0.40 \\
Vegetation & 98.3 & 16.24 & 125.6 & 20.75 \\
bare soil & 431.1 & 71.23 & 323.8 & 53.49 \\
Settlement & 74.6 & 12.32 & 153.3 & 25.33 \\
\hline
\end{tabular}

waterbody increased from $1.1 \mathrm{~km}^{2}$ to $2.5 \mathrm{~km}^{2}$, and bare soil reduced from $431.1 \mathrm{~km}^{2}$ to $323.8 \mathrm{~km}^{2}$. In between these years, urbanization and industrialization have happened at a very greater rate i.e., $105.54 \%$ in the study area due to population growth and developmental activities as it is very nearer to Bengaluru city. There has been a significant decline in the bare soil i.e., $24.89 \%$ because most of the land was converted into plantation and settlement. Table 3 and Fig. 7 highlights the percentage of changes in LULC classes in the study area. Accuracy assessment was done by a random sampling method by selecting 200 sampling points to check the accuracy of the classified images. The outcomes of this analysis indicate that the overall accuracy for the classified images of the years 2000 and 2018 is $92.31 \%$ and $87.50 \%$,

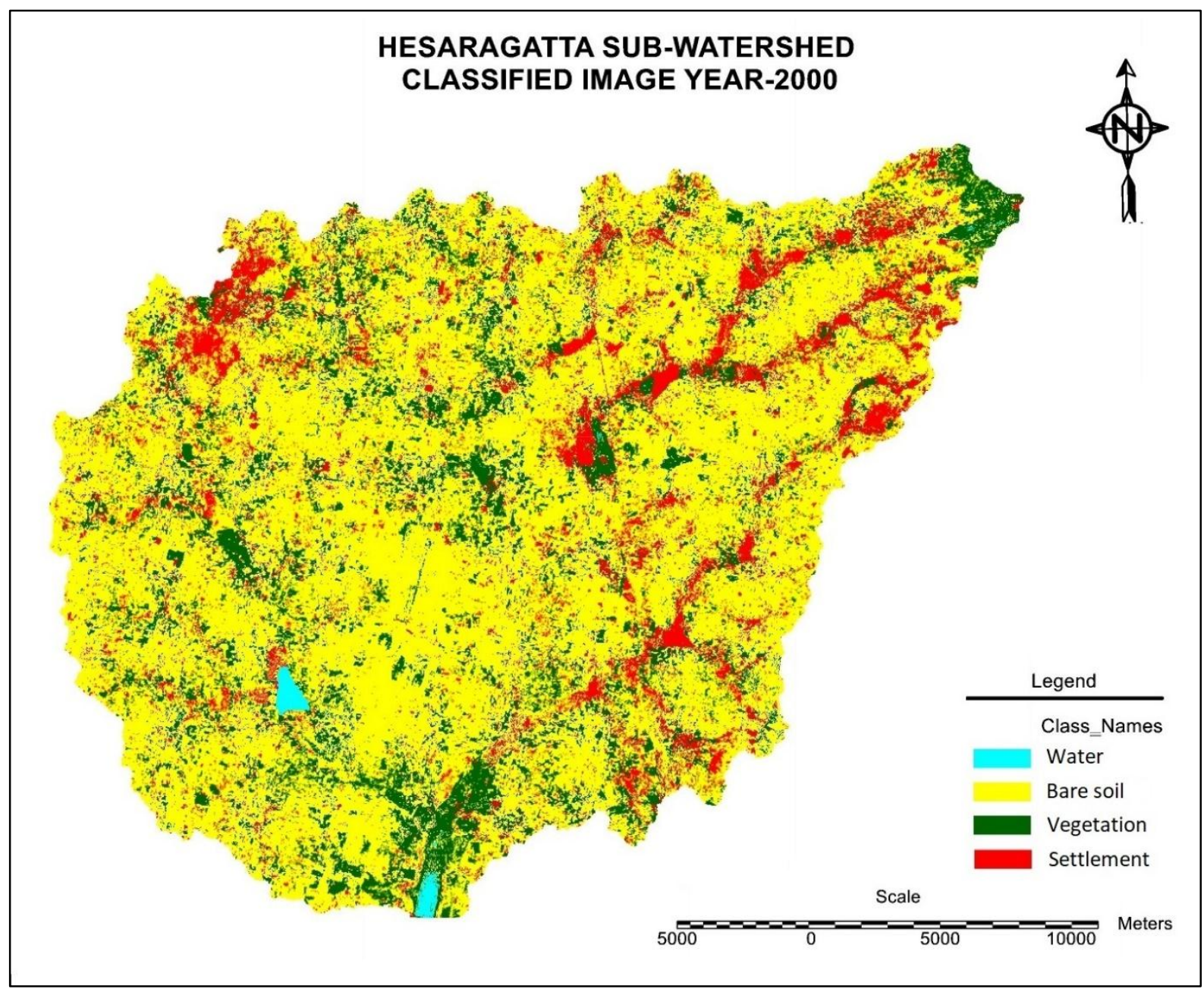

Fig. 4: LULC map of Hesaraghatta watershed, 2000. 


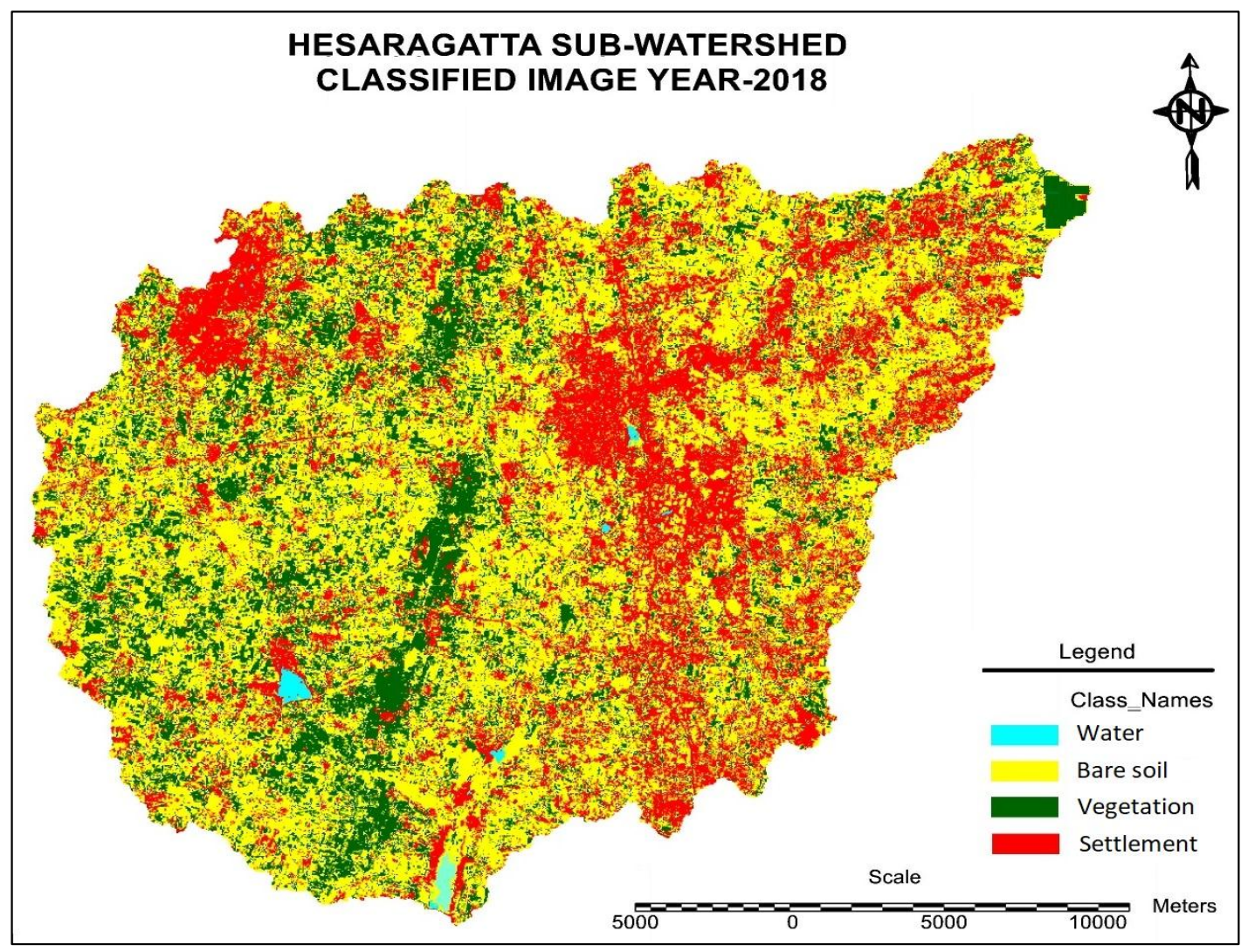

Fig. 5: LULC map of Hesaraghatta watershed, 2018.

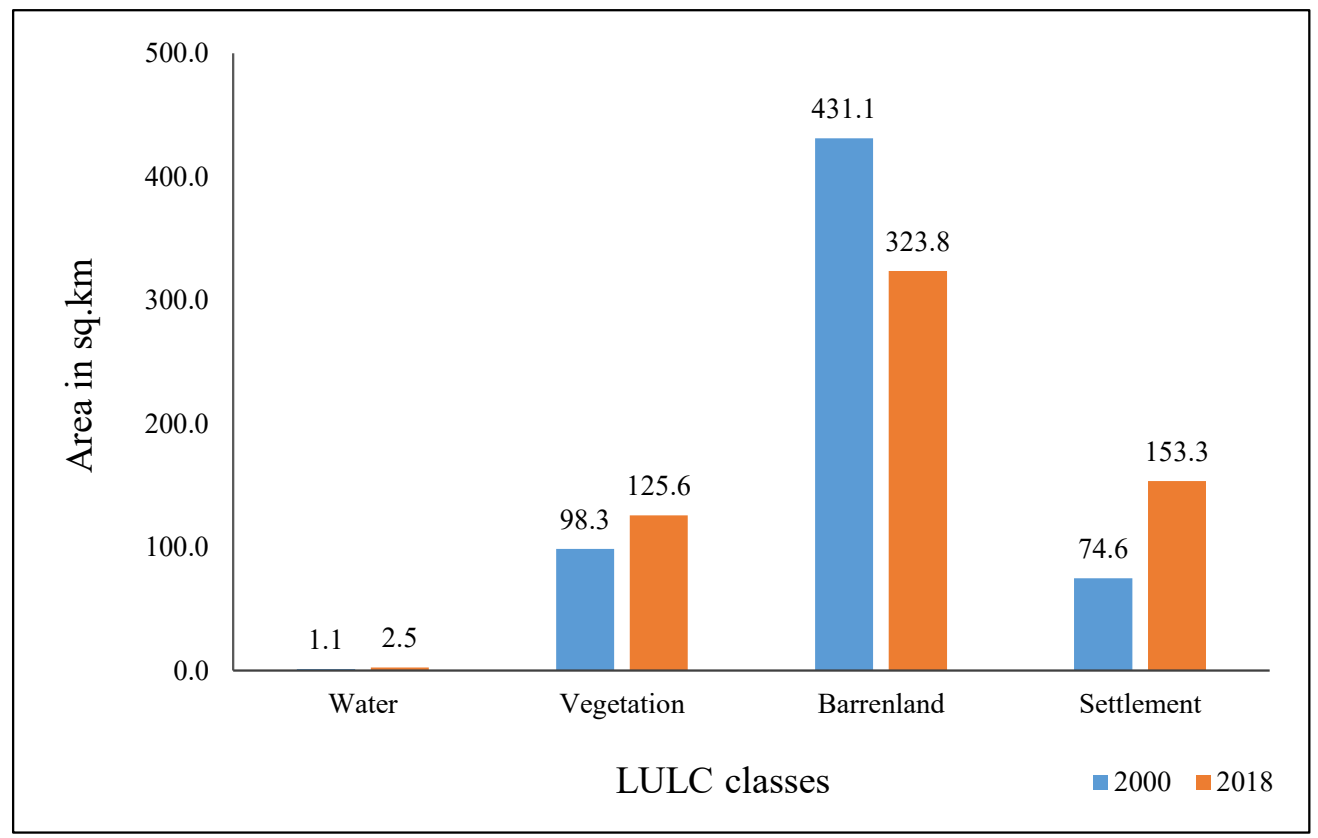

Fig. 6: Distribution of various LULC classes in the Hesaraghatta watershed. 


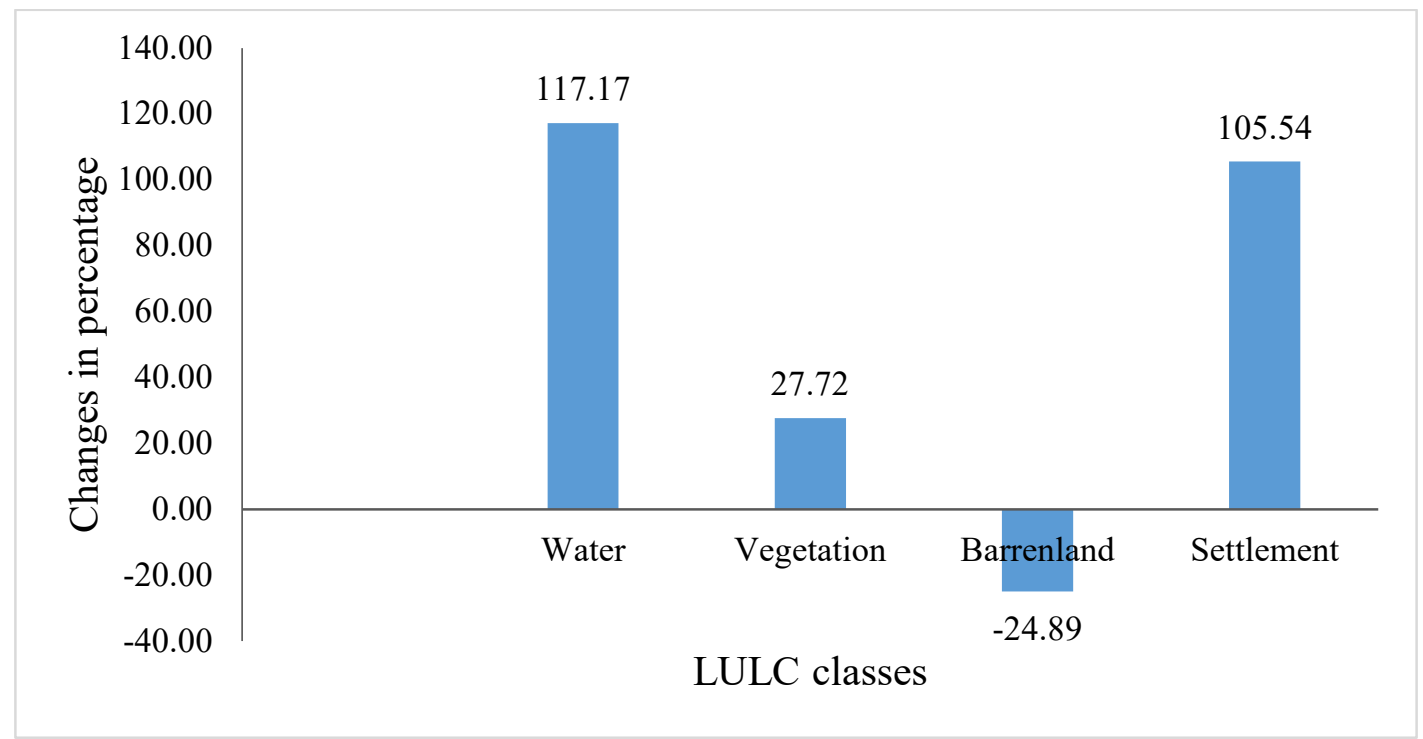

Fig. 7: Change in LULC classes from the year 2000 to 2018 in percentage.

Table 3: LULC assessment of Hesaraghatta watershed area.

\begin{tabular}{|lllll|}
\hline \multirow{2}{*}{ LULC class } & LULC in 2000 & LULC in 2018 & \multicolumn{2}{c|}{$\begin{array}{l}\text { Change in the area from } 2000 \text { to } \\
2018\left(\mathrm{~km}^{2}\right)\end{array}$} \\
\cline { 2 - 3 } Water & Area $\left(\mathrm{km}^{2}\right)$ & Area $\left(\mathrm{km}^{2}\right)$ & 1.3 & 117.17 \\
Vegetation & 1.1 & 2.5 & 27.3 & 27.72 \\
Bare soil & 98.3 & 125.6 & -107.3 & -24.89 \\
Settlement & 431.1 & 323.8 & 78.7 & 105.54 \\
\hline
\end{tabular}

and Kappa co-efficient for those years are 0.909 and 0.822 respectively. The Kappa coefficient values obtained portray that the accuracy of the image classification is acceptable.

\section{CONCLUSION}

The current study aimed at assessing the change in LULC classes in the Hesaraghatta watershed. This study discloses that the LULC pattern in the Hesaraghatta watershed has transformed significantly over 18 years. It is detected that there has been an escalation in the settlement in the study area due to population growth and developmental activities and it is also noticed that there is an increase in vegetation due to an increase in plantation, thereby reducing the amount of bare land. This study has also revealed that integration of GIS and Remote sensing can be a powerful tool for mapping and assessment of LULC changes in an area. Though, the accuracy of results is greatly influenced by interpretation.

\section{REFERENCES}

Abd El-Kawy, O.R., Rød, J.K., Ismail, H.A. and Suliman, A.S. 2011. Land use and land cover change detection in the western Nile delta of Egypt using remote sensing data. Appl. Geog., 31(2): 483-494. https://doi. org/10.1016/j.apgeog.2010.10.012

Ali, D., Batool, S., Techato, K., Gyawali, S. and Suklueng, M. 2020. GISMCDM approach to determine forest plantation areas in the U-tapao river basin in Songkhla, Thailand. Int. J. Integr. Eng., 12(2): 294-301. https://doi.org/10.30880/ijie.2020.12.02.033

Anees, M.T., Abdullah, K., Nawawi, M.N.M., Rahman, N.N.N.A., Piah, A.R.M., Syakir, M.I., and Mohd Omar, A.K. 2017. Effect of upstream on downstream due to spatio-temporal land use land cover changes in Kelantan Peninsular, Malaysia. Nat. Environ. Pollut. Technol., 16(1): 29-35.

Belay, T. and Mengistu, D. A. 2019. Land use and land cover dynamics and drivers in the Muga watershed, Upper Blue Nile basin, Ethiopia. Remote Sens. Appl.: Soc. Environ., 15: 100249.

Bharath, A., Manjunatha, M., Tangadagi, R.B. and Preethi, S. 2020a. Environmental assessment for rainwater harvesting at GITAM Campus. J. Green Eng., 10(4): 1776-1785.

Bharath, A., Preethi, S., Manjunatha, M. and Tangadagi, R. B. 2020 b. Prediction of temperature data for Ghataprabha. Sub. Eco. Env. \& Cons., 26: 140-144. 
Butt, A., Shabbir, R., Ahmad, S.S. and Aziz, N. 2015. Land-use change mapping and analysis using Remote Sensing and GIS: A case study of Simly watershed, Islamabad, Pakistan. Egypt. J. Remote. Sens. Space Sci., 18(2): 251-259. https://doi.org/10.1016/j.ejrs.2015.07.003.

Chen, W., Chi, G. and Li, J. 2019. The spatial association of ecosystem services with land use and land cover change at the county level in China, 1995-2015. Sci. Total Environ., 669: 459-470. https://doi. org/10.1016/j.scitotenv.2019.03.139

Chowdhury, M., Hasan, M.E. and Abdullah-Al-Mamun, M.M. 2020. Land use/land cover change assessment of Halda watershed using remote sensing and GIS. Egypt. J. Remote. Sens. Space Sci., 23(1): 63-75.

Das Kangabam, R., Selvaraj, M. and Govindaraju, M. 2019. Assessment of land use land cover changes in Loktak Lake in Indo-Burma Biodiversity Hotspot using geospatial techniques. Egyptian J. Remote Sens. Space Sci., 22(2): 137-143. 5

EarthExplorer. (n.d.). USGS. https://earthexplorer.usgs.gov/ (accessed January 4, 2021)

Garg, V., Nikam, B.R., Thakur, P.K., Aggarwal, S.P., Gupta, P. K. and Srivastav, S.K. 2019. Human-induced land uses land cover change and its impact on hydrology. HydroResearch, 1: 48-56.

Gebeyehu, A.E., Chunju, Z. and Yihong, Z. 2019. Assessment and mapping of land-use change by remote sensing and GIS: A case study of Abaya Chamo Sub-basin, Ethiopia. Nat. Environ. Pollut. Technol., 18(2): 549-554.

Imran Basha, U., Suresh, U., Sudarsana Raju, G., Rajasekhar, M., Veeraswamy, G. and Balaji, E. 2018. Landuse and landcover analysis using remote sensing and GIS: A case study in the Somavathi river, Anantapur district, Andhra Pradesh, India. Nature Environ. Pollut. Technol., 17(3): 1029-1033.

Mallupattu, P.K. and Sreenivasula Reddy, J.R. 2013. Analysis of land use/ land cover changes using remote sensing data and GIS at an Urban Area, Tirupati, India. Sci. World J., 2013: 1-7.

Nayak, P.M. and Byrne, M.L. 2019. Impact of land use land cover change on a sand dune ecosystem in Northwest Beach, Point Pelee National Park, Canada. Journal of Great Lakes Research, 45(6): 1047-1054.

Preethi, S., Tangadagi B.R., Manjunatha, M. and Bharath, A. 2020. Sustainable effect of chemically treated aggregates on bond strength of bitumen. J. Green Eng., 10(9): 5076-5089.

Rimal, B., Sharma, R., Kunwar, R., Keshtkar, H., Stork, N. E., Rijal, S., Rahman, S. A. and Baral, H. 2019. Effects of land use and land cover change on ecosystem services in the Koshi River Basin, Eastern Nepal. Ecosyst. Serv., 38: 100963.

Salunke, S. and Chavan, B. 2020. Imperious approach towards justifiable strategic lake sediment regulation. Nature Environ. Pollut. Technol., 19(1), 339-348.

Somashekar, R.K., Ravikumar, P., Sowmya, S.V., Dar, M.A., and Ravikumar, A.S. 2011. Runoff estimation and morphometric analysis for Hesaraghatta watershed using IRS-1D LISS III FCC satellite data. J. Indian Soc. Remote Sens., 39(1): 95-106.

Tsai, Y.H., Stow, D., An, L., Chen, H.L., Lewison, R. and Shi, L. 2019. Monitoring land-cover and land-use dynamics in Fanjingshan national nature reserve. Appl. Geog., 111: 10-20

Wang, L., Wang, S., Zhou, Y., Zhu, J., Zhang, J., Hou, Y. and Liu, W. 2020. Landscape pattern variation, protection measures, and land use/land cover changes in drinking water source protection areas: A case study in Danjiangkou Reservoir, China. Global Ecol. Cons., 21: e00827.

Wang, X., Gong, W., Huang, X., Liu, T., Zhou, Y. and Li, H. 2018. Assessment of eco-environmental quality on land use and land cover changes using remote sensing and GIS: A case study of Miyun county. Nat. Environ. Pollut. Technol., 17(3): 739-746. 